THE

\title{
GEOLOGICAI、M AGAZINE.
}

VOL. LXXII OF WHOLE SERIES.

JANUARY-DECEMBER, 1935. 
THE

\section{GEOLOGICAL MAGAZINE \\ OR}

\section{Sinontble Fournal of Geology.}

WITH WHICH IS INCORPORATED

THE GEOLOGIST.

Foundfo in 1864 by the late Dr. Henry Woodward, F.R.S.

EDITED BY

R. H. RASTALL

A.N1

o. M. B. BULMAN.

ASSISTED BY

PROFESSOR W. S. BOULTON, D.SC.

Sir T. H. HOLLAND, K.C.S.I., D.SC., F.R.S.

Professor O. T. JONES, M.A., D.Sc., F.R.S.

PRofEsSOR W. W. WATTS, SC.D., IL.D., M.SC., F.R.S.

HENRY WOODS, M.A., F.R.S.

SIR ARTHLR SMITH WOODWARD, LL.D., F.R.S.

VOL. LXXII OF WHOLE SERIES.

IANUARY-DECEMBER, 1985.

LONDON :

DULAU \& CO., LTD.,

2 STAFFORD STREET, OLD BOND STREET, W. 1.

1935. 
HERTFORD

STEPHEN AUSTIN AND SONS, LTD. 


\section{CONTENTS OF VOLUME IJXXII, 1935.}

No. 847.

JANCARY .

PAGE

F. J. Turner and C. O. Huttox. Stilpnomelane and Related

Minerals in Western Otago

W. F. Hume, H. F. Harwood, and L. S. Theobald. Analyses of Egyptian Rocks (with petrographical notes by A. I. Awad)

F. R. C. REeD. Triassic Lamellibranchs from Brazil and Paraguay . . . . . . . . 33

E. S. CobBold. A Middle Cambrian Hyolithellus from Comley 43

Reviews-Geology of the Country between Springs and Bethal, 45 ; Crystals and the Polarizing Microscope, 45; Leeds Geological Association, 46 ; Useful Aspects of Geology, 46; Minerals of the French Colonies, 47 ; Geological Model of Ardnamurchan, 47.

ConRespondence.-S. E. Hollingworth, 48.

No. $848 . \quad$ February.

F. WALKer and C. F. Davidson. Marginal and Contact Phenomena of the Dorback Granite

R. G. Lewis. Influence of Earth Movements on Climate . 64

J. G. C. Anderson. The Dalradian Succession in the Pass of Brander, Argyll .

S. Eldoer. Comparison of Three Scottish Magmas . . 80

S. J. Shand. An Olivine-Trachyte from Auvergne . . . 86

J. P. T. Burchell. Glacial Episode of the Lower Thames . 90

F. Jones. The Occurrence of Markfieldite at Nuneaton . . 91

Reviews.-Geology of Uganda, 93; Chromite Deposits of Newfoundland, 94.

Reports axd Procendngs.-Geological Society, 94; Mineralogical Society, 95 .

Correspondence.-P. Jessop, 96.
No. 849.
March.

G. A. Joplin. A Diorite-Limestone Reaction at Ben Bullen, N.S.W.

A. J. Butler. On the Silurian Coral Cyathaxonia siluriensis M'Coy

R. H. Rastall and J. E. Hemingway. The Petrography of the Blea Wyke Series

E. J. Duns. Australites . . . . . . . . $\quad . \quad 139$

G. S. Blake. On the Occurrence of Marine Miocene in Palestine 140

Reviews.-Geology of the Baltic, 142 ; Geologic Structures, 142.

Correspoxofece.-E. W. Berry, 143 ; E. S. Cobbold, 144. 


\section{Contents.}

No. 850 .

APriL.

PAGE

Selwyn Turner. Gotlandian Vulcanicity in Western

Europe . . . . . . . . . 145

B. BaIley. The Glencoul Nappe . . . . . 151.

H. Simpson. Marine Band in the Denbighshire Coalfield . 165

T. Trechmann. Fossils from the Northern Range of

Trinidad . . . . . . . . . 166

D. Thomas. Some Sponges and a Coral from Trinidad . $\quad 175$

Hanson-Lowe. The Clinographic Curve . . . . 180

F. Spath. Trigonia from the Jurassic Rocks of Kachh . 184

:vIEws.-Geology of Libya, 189 ; Stegocephalians and Primitive Reptiles,

190.

:PORTS AND Procendings.-Mineralogical Society, 191.

RRESPONDENCE. - S. H. Haughton, 192.

No. 851 .

MAY

Wright. New Crinoids from Caplow Knoll, Clitheroe, with

lists of Carboniferous Limestone Crinoid Species . . 193

A. Moy-Thomas. Coelacanth Fishes from Madagascar . 213

A. Joplis. Origin of Basic Xenoliths in Plutonic Rocks . 227

views.--The Geology of Burma, 235; Mineral Resources of Burma, 237 ;

The End of the Palaeolithic, 238.

RRESPONDENCE.-L. C. W. Bonacina, 240.

No. 852.

JUNE.

Wood. The Origin of Guilielmites . . . . . 241

J. Arkell. Lower Kimeridgian Ammonites . . . 246

Harrison. The March-Nar Sea . . . . . . 257

G. C. Anderson. The Arrochar Complex . . . . . 263

vIEws.-Gemstones, 283; The Ice Age, 283; Geology of Africa, 285;

The Sudbury Nickel Irruptive, 285; Glacial Geology of E. Yorks, 287.

RRESPONDENCE.-E. Greenly, 287 ; F. E. Suess, 288.

No. 853.

JULY.

R. Nockolds. Contributions to the Petrology of Barnavave, Carlingford

K. S. ST. Joseph. Description of Eospirifer radiatus (J. de C.

Sowerby) .

P. T. Burchell. Pleistocene Deposits at Kirmington and

Crayford . . . . . . . . . .

views.-Petrography of Igneous Rocks, 332; Earthquakes and

Mountains, 332.

poRTS AND PROCEEDTNGS.-Mineralogical Society, 333.

3RESPONDENCE.-W. C. Simmons, 335 ; J. Fowler, 335 ; G. Vibert Douglas and J. F. Forster, 336. 
W. H. Barrett. Mechanical Composition of the Tertiaries near Harrow . . . . . . . .

J. T. Stark and F. F. Barnes. Correlation of Granite by Heavy Mineral Analyses . . . . . . 341

F. E. Zeuner. The Pleistocene Chronology of Central Europe 350

P. R. Thompson. Thermal Contraction, Land Bridges, and Geosynclines

REview.-Geology of the Orkneys, 381 .

Correspondence.-C. N. Fenner, 381; S. J. Shand, 382; A. W. Woodland, 384.

No. 855 .

SEPTEMBer.

G. A. Joptin. The Exogenous Contact-zone at Ben Bullen, N.S.W.

J. K. S. Sr. JosEph. Critical Examination of Stricklandia lirata (J. de C. Sow.) forma typica . . . . . . . . 401

H. Dighton Thomas. Tricycloseris, Anabacia, and some new Genera of Hexacoralla

Review.-Roman Mines in Europe, 430.

Correspondence.-R. G. Lewis, 431 ; Geological survey Centenary, 432.

No. 856.

OCTOBER.

S. V. Semichatov. The Middle Carboniferous of Russia . . 433

C. W. Wright. The Chalk Rock Fauna in East Yorkshire . 441

J. A. SteErs. Rate of Sedimentation on a Salt Marsh . . 443

J. A. Moy-Thomas and T. S. Westoll. On Coelacanthus granulatus Ag. . . . . . . . . 446

J. Selwyn Turner. Dinantian and Namurian Vulcanicity . 458

S. C. A. Holmes. The Periproctal Plates of Discoidea . . 470

Reviews.-Problems of Petroleum Geology, 479; Mineral Resources of French Colonies, 480.

No. 857 .

November.

D. HiLl. British Terminology for Rugose Corals .

E. M. KindLE. Lime-separating Algae from Subarctic Canada

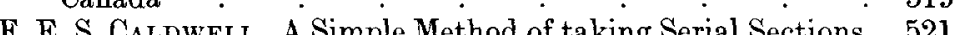

Reviews.-British Regional Geology, 523; Petrology for Students, 526; The Dorset Coast, 527 .

Correspondence.-T. S. Westoll, 528. 
No. 858.

C. T. Trechmann. The Geology and Fossils of Carriacou,

West Indies . . . . . . 529

E. Dix. Flora of the Highest "Coal Measures" of

Warwickshire. . . . . . . . 555

Reviews.-Introduction to Palaeontology, 558; Swedish Liasso-Rhaetic

Floras, 558; Structural Geology, 560; Brunner Focal Chart, 560.

Reports and Proceedixgs.-Mineralogical Society, 561.

ANNOUNCEMENTS.-562.

INDEX.- -563 . 